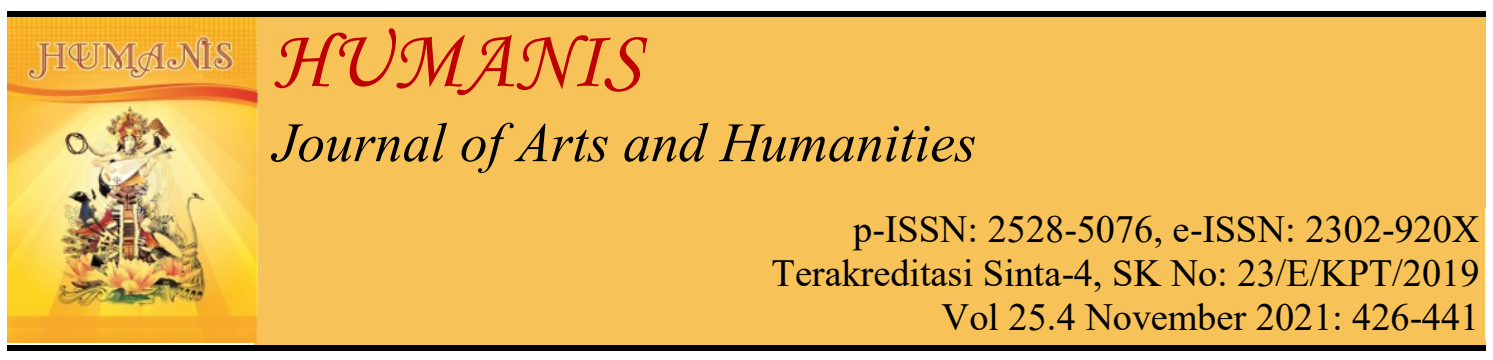

\title{
A Quixotic Venture: Spanish-Philippine Poetry at the Turn of the 19th Century, or Resistance against Oblivion
}

\author{
Mario Sánchez Gumiel \\ University of Michigan-Ann Arbor, Ann Arbor, Michigan, United States \\ Correspondence email: msgumiel@umich.edu
}

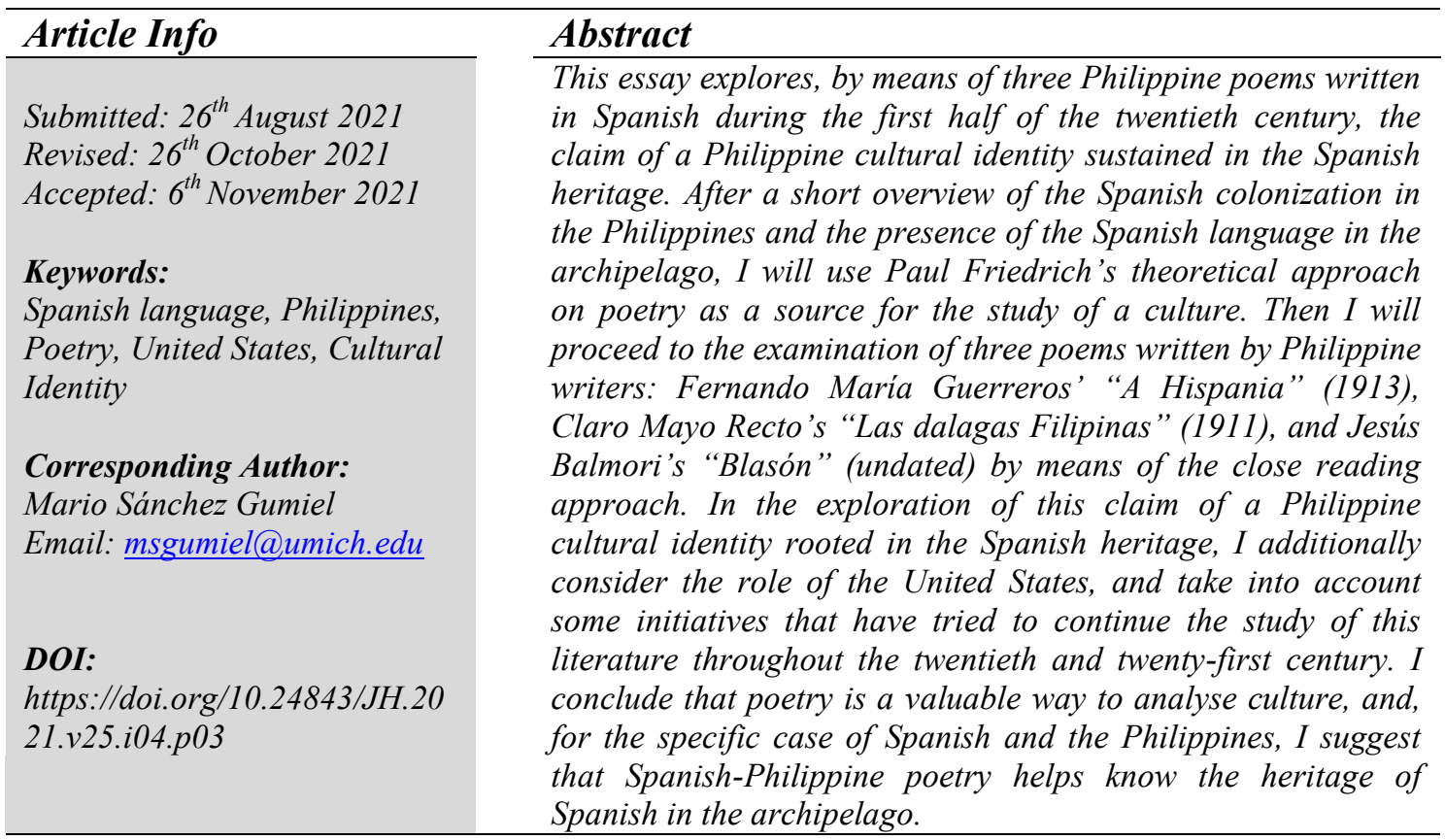

\section{INTRODUCTION}

The archipelago that today forms the Philippines was encountered in 1521 by the expedition of Fernando de Magallanes (1480-1521). After this expedition, another four occurred: García Jofre de Loaysa's (1525), Álvaro de Saavedra Cerón's (1527), Ruiz de Villalobos' (1541), and Miguel López de Legazpi \& Andrés de Urdaneta's (1565). Urdaneta and Legazpi were those who finally dealt with the annexation of this territory to the Crown of Castile. Thus, by the second half of the sixteenth century, Spain accomplished the aim of extending to Asia both the colonialist and the evangelistic tasks that it had initiated in the American continent in 1492 (González Pola, 1992: 5-6).

Although many religious orders participated in that evangelistic task, the number of monks who were mobilized to the Philippines was substantially smaller than those who went to America, affecting, as a result, both the missionary work and the implementation of the Spanish language in the islands. For example, it was not until Villalobos' expedition (1541) that the first missionaries (the Dominicans; eight, to 
be precise) arrived to the islands. In Legazpi and Urdaneta's expedition (1565), five more missionaries arrived. It would not be then until 1578 that this number of thirteen monks would grow. The first group of Franciscans arrived the same year (1578) and, soon after, in 1581, the first Jesuits landed. The Dominicans became the most influential religious group in the islands, and they established, between the biennium 154041 and 1586, seven provinces under the domain of this Order as well as numerous convents and doctrines.

Dominican evangelization was developed in two stages. The first stage (1540-45) was infructuous due to the lack of authorization by the king Carlos V (1519-56) and the Pope Pablo III (1534-49). The second stage was promoted by Friar Domingo de Salazar (1512-94), who, according to Robert Richmond Ellis (2012), was considered by the Spanish king Felipe II (1556-98) a sort of "Asian" Bartolomé de las Casas (Richmond Ellis, 2012: 139). This second stage was also infructuous, with only fifteen monks arriving in the archipelago in 1587. Conversely, Salazar accomplished the difficult goal of legalizing the Philippines as a province of the Dominican Order by the Council of Indies, and he got financial support from the king Felipe II. That process of legalization was, however, extremely slow and exasperating (González Pola, 1992: 6-7). Distance, time and slowness thus characterized the evangelist beginnings in the Philippines, as well as the beginning of the Spanish language in this archipelago - a beginning that, in a sense, preluded the secondary status of the Philippines within the Spanish colonization if compared with Latin America, eventually affecting the study of Philippine literary and cultural production in Spanish as well.

Historians and linguists disagree on how real and verifiable the presence of
Spanish in the Philippines is. Did it really become ingrained in the archipelago just as it became ingrained in America? Linguists like John Lipski (1986-87) or Antonio Quilis (1992, 2003) have agreed that Spanish is a language that never took over in the Philippines in the same way that it did in America. For his part, Alonso Zamora Vicente (1967) stated that, at the end of nineteenth century only the $10 \%$ of the Philippine population spoke Spanish, mostly concentrated in upper classes (Zamora Vicente, 1967: 449)

Those who however have reclaimed the presence of Spanish, its validity and its contribution to the Philippine identity are mainly Philippines Hispanists, such as Guillermo Gómez Rivera (2008, 2012), Florentino Rodao (1997) or Edmundo Farolán (2002), who have argued that, if nowadays people still say that the Philippines is not a country where Spanish is (or was) spoken, that is because those people have been yielded by the policy of linguistic destruction that the United States carried out since its arrival to the archipelago in 1898 , once the rule by the Spanish Empire ended (Lipski, 1986-87: 37-48; Quilis, 2003: 1060-1069; Quilis, 1992: 661-672; Gómez Rivera, 2009 [2012]). This vindication of the Spanish language/culture in the archipelago has not been circumscribed to Philippine Hispanists. For instance, Manuel Alvar (1996) states that children's school attention at the turn of the nineteenth century was higher than, for example, in France-by then, one of each thirty-eight children in the Philippines went to school while, in France, one of each thirty-four (Alvar, 1996: 233). On his behalf, Linguist David Pharies (2008) calculates that, whereas nowadays only around the $1 \%$ of the Philippine population speak Spanish, there are many dialects in the islands that are very close to this 
language as, for example, the chabacano (Pharies, 2008: 209).

Three are the reasons used by those who argue that Spanish is a language that did not find support in the Philippines when the United States took the control of the archipelago as of 1898: the existence of a highly fragmented territory, an enormous distance from Spain, and a very limited movement of people between the mother country and the colony. Contrary to America, the fragmentation of the Philippine territory was always a problem for Spaniards since every island represented, to some extent, a world of its own with its own language, its own culture, and its own rules. The evangelistic mission of those who moved there always was something excessive and very complicated. Moreover, the (extremely warm and wet) weather and the lack of both gold and other riches if compared with America positioned the archipelago in a secondary place within Spaniards' priorities. Somehow, all these aspects contributed to the slow development of Spanish, not being until the nineteenth century that the first signs of real establishment of the language (and, most important, of the use of that language as a symbol of nationalism) was appreciated.

The first signs of the establishment of Spanish in the Philippines were because of the instauration of the obligatory nature of its teaching in schools, the improvement in the communications (especially the telegraph), and the development of the press. This social context derived in the development of a Philippine nationalism that sought its roots in its Spanish heritage concomitant with its Asian location (Rafael, 1999). This incipient process of consolidation of Spanish was however stopped because of both the arrival of Americans in 1898 after the Spanish-American War (April 21-August 13, 1898), and the implementation of
English. Although Spanish and English coexisted with identical official status until the Second World War, the Japanese invasion, the attempt to implement the Japanese language, and the defeat of the Axis in 1945 helped accelerate the process of disintegration of Spanish (Rodao, 1997: 104-105).

As of 1946, the instauration of Tagalog as official language and an extended use of English made Spanish the third language in the archipelago along with Arabic. In 1987, the government of Corazón Aquino (198692) decreed the suppression of the obligatory nature of teaching Spanish in schools, and it was not until 2002 that President Gloria Macapagal-Arroyo (2001-10) reinstalled the possibility of its study in the all-educational levels. As a result, this loss of presence for almost half a century led to overlook Philippines as a place that is part of the cultural production in Spanish, literature included.

\section{Spanish in the Philippines at the Turn of the 19th Century}

The arrival of the United States to the Philippines in 1898 meant a turning point in both the history of the archipelago and the history of the United States, representing the change of a foreign power in the control and rule of the country as well as the rise of the United States' awareness of its international strength and influence. Until then, the United States had been relatively isolated from international conflicts, but presidents William McKinley and Theodore Roosevelt's policies seeking to expand the American influence around the world began to change this tendency.

Embodied with its principles of liberty, democracy and economic development, the United States sought in the Philippines a sort of influence that would not resemble (despite its 
similarities) the manners of Old European imperialistic powers. Its purpose was to impose those principles of liberty and democracy not by force but by persuasion. They claimed not only that they were good, but also that they owned the only principles that could help to develop a poor country as the Philippines. In his book Constitutional Government (1908), former president Woodrow Wilson stated that

[w]e [the United States] can give the Filipinos constitutional government, a government which they may count upon to be just, a government based upon some clear and equitable understanding, intended for their good and not for our aggrandizement; but we must ourselves for the present supply that government [...] But we cannot give them self-government. Selfgovernment is not a thing that can be "given" to any people [...] Only a long apprenticeship of obedience can secure them the precious possession, a thing no more to be bought than given (Wilson, 1908: 52-53).

The purpose of the United States was not to establish itself as a colonizer in the archipelago just as Spain had done for more than three centuries. Its purpose rested on the Philippine people having learnt and adopted a democratic culture to rule by themselves. To establish these democratic principles implied, however, to destroy existent structures, language and culture included.

There is no question that the United States accomplished in a very brief period of time many things that the Spaniards never were able to achieve in more than three centuries. At the end of the first decade of the twentieth century, the policy of the United States of imposing the English language to the Philippine population seemed to have already succeeded. In addition to this imposition, there was also a process aimed at perceiving Spanish as a useless language by considering it a religious, cultural language only. That is, as a language whose only reason to be taught was to learn God's Word, and therefore to convert Philippines to Catholicism. As opposed to Spanish, Americans inculcated the idea that English was useful because it was a commercial language - a language with a purpose in daily life. In an article of 1903 for Gunton's Magazine, Burgess Shank expressed that

Spanish became the language of culture in the Philippines, in spite of the Spaniards having made themselves hated. Our attempt, being much more extensive and intelligent, and having benevolent motive, must therefore be many times as effective. In this connection it is fair to ask why the Spaniards were so slow in civilizing and educating the Filipinos [...] America is doing more in years than Spain did in decades $[\ldots]$ To teach and to learn a language with a practical aim is much easier than when the aim is "educative or cultural." Interest is infinitely greater (Shank, 1903: 406).

Many Americans, however, resisted this linguistic policy. In that sense, Spanish survived almost half a century in the Philippines in part due to the work of many American private (and religious) educational institutions, which decided to continue educating in Spanish instead of using English. This decision was not exempt of controversy and confrontation between Americans. For example, Theodore de Laguna (an American teacher at El Salvador, on the island of Mindanao) considered the American attempt to educate the Philippine people in English as "a monstrous, mortifying 
failure" (qtd. in Shank, 1903: 406). Hence, during the first half of the twentieth century the Philippines experienced a similar situation to that which they had lived with the arrival of Spaniards in the sixteenth century.

What was the attitude of the Philippine population towards this change of colonizer, but not of its condition of colonized? If we trust Shank's words above, it seems that the Philippines readily accepted this new situation. Yet resistance existed. That resistance against this situation was developed by educated people; people with Spanish ancestors, or people related, to some extent (by work, by travel, etc.), with the former mother country. The fight, however, was never extended, and it did not find much support either in Spain (in those years, sunken in a dramatic economic, cultural and political crisis), or by Spanish-American nations (then seeking the Latin American identity as opposed to the US identity). It was, to sum up, a very personal, reduced effort which nevertheless lived an important literary time (it is included in the socalled "Golden Age of Philippine Literature"), at least until the end of Second World War.

Today, Spanish-Philippine literature is somehow seen as something rare. With increasing exceptions, it is still perceived as separated from both Spanish Peninsular and Spanish-American literatures, both profusely studied by academia. It is contemplated as the product of a specific historical context rather than as the true expression of a culture that could be considered part of the Hispanic world. Although there were many positive aspects during Macapagal's govern, such as the aforementioned instauration of Spanish in education, and the existence of a literary prize for literature written in Spanish (the Zobel Prize), Rodrigo Duterte's govern (2016 - ?) has acted less enthusiastically, reducing the funding, for example, for academic institutions, or for the aforementioned Zobel prize, as well as suggesting the possibility of changing the name of the country for Maharlika in order to distance it from its colonial past. Philippine people still use English or Tagalog as main languages to communicate between them, and Spanish faces the paradoxical situation of having to be learned in a place that occupied for three centuries. The fact that the use of Spanish between Philippine people is still reduced to upper classes (even if languages like Tagalog or chabacano include Spanish words) ultimately converts Spanish-Philippine literature into something very selective and not accessible for everybody.

However, Philippine writers who write in Spanish exist(ed). For instance, Jesús Balmori (1887-1948), José Rizal (1861-96) (who is considered Philippines' national hero), or Claro Mayo Recto (1890-1960). Their novels often deal with melodramatic plots, paying much attention to the exotic, beautiful Philippine landscape(s), and mostly contextualizing the events in key historical moments, turning the novels into something more than simply melodramas. For example, one of the most popular Philippine novels (Jesús Balmori's Los pájaros de fuego [1945]) locates the story during World War II to narrate the vicissitudes of a family. Although it uses an exaggerated romantic tone and style, the novel is also the serious depiction of how many Philippines tried to adopt, during the war conflict, the Japanese culture by denying their own Philippine cultural identity (Lifshey, 2011: 18). Other novels that present this combination of melodrama and historical events are José Rizal's Noli Me Tángere (1887) and its sequel, El filibusterismo (1891), which explore the injustices of Spaniards' government in 
the Philippines at the end of the Spanish Empire.

Similar combination of melodrama and historical context is produced in Spanish-Philippine poetry, but, unlike novels, Spanish-Philippine poetry is, however, less known (Farolán, 2002). With some exceptions (Jesús Balmori's Mi casa de Nipa [1941]), most of this poetry of late nineteenth century/early twentieth century, though not forgotten, remains in semi-oblivion. As said before, it follows similar pattern of combining historical references and an affected, precious style. It is a poetry strongly influenced by Modernism, a movement that was very popular in Latin America during the nineteenth century, but almost extinguished by the turn-of-the-centurya poetry, in turn, where the use of delicate imagery as swans, vivid colours, sense of clearness, purity, and a strong emphasis in sensorial stimulus was (is) continuous: "Modernist poetry [...] shows [...] metric renewal, renewal in poetic vocabulary, aestheticism, exoticism, idealization of the 18th century, introduction of a new female type, epicureism [and] exaltation of Classical Greece" (Salvetti, 2019: Par. 6).

Hence, Spanish-Philippine literature remains in a paradoxical situation. We can say that its existence is recognized, yet this recognition still suffers from being seen as something exotic inside the world of Hispanophilia-i.e., because its influence seems irrelevant today, it does not deserve to be studied in the same way that both Spanish Peninsular and Spanish-American literatures do.

\section{METHOD AND THEORY}

\section{Poetry as a Source for the Study of a Culture}

Although the overview above does not cover all the complexity of the history of Spanish in the Philippines, it serves to introduce the type of scenario where I want to develop the topic of this article. My purpose here is to explore, by means of a few Philippine poems written in Spanish during the first half of twentieth century, the claim of a Philippine cultural identity sustained in the Spanish heritage. By combining close readings and using Paul Friedrich's theoretical approach on poetry as a source for the study of a culture, I examine the poems written by three Philippine writers: Fernando María Guerreros' A Hispania (1913); Claro Mayo Recto's Las dalagas filipinas (1911), and Jesús Balmori's Blasón (undated).

The value of poetry for the study of a given culture rests, according to Paul Friedrich, on what that poem signifies for the construction of a worldview (Friedrich, 1996: 38). To discover a worldview is not only to discover an external, physical world, but also to discover an internal one. Thus, the goal of studying poetry

is not only to get a worldview but to get inside a worldview, to construct texts of one's own that reveal maximum empathy and comprehension [because] [w] hen we looked at this way, the poems or songs that one finds, particularly when they are generally known and instantly understood by people, can constitute an incredibly swift and sensitive entryway (Friedrich, 1996: 39).

When the social scientist goes into the inner worldview that poetry entails, what he/she is discovering are emotions and intuitions, which means,

the cultural experience as felt as well as understood - that is, in psychological terms, the phenomena of intention, identification, motivation, and affect that are often 
neglected in cultural analysisincluding much of the recent research that combines an ideology of emotionality with practices that feature analytical instruments and objectivized data (Friedrich, 1996: 39).

Poetry then becomes, for the study of a culture, both "data" [my quotes] for analysis and a body of generalizations about life that are "at least as subtle as what the social scientist normally comes up with" (Friedrich, 1996: 39).

In addition to this, Friedrich claims that "language is a product of consciousness, but consciousness is also a product of language" (Friedrich, 1996: 41). This sentence is the result of a previous thought process of his where he has drawn three different levels when speaking about poetry, language and consciousness. In the first level, the words of a poem act as verbal expressions of consciousness which help individuals to live. In a second level, the words of a poem can represent what is not said within that poem, which means, what is beyond the mere verbalization of consciousness. In the third level it is language, from which derive both the verbalization and non-verbalization of consciousness. Here Friedrich is close to Barthes' argument regarding the text and the author. In "The Death of the Author," Barthes considers that, after the retreat of the author as the only plausible explanation of the text, his/her raison d'être was only to be the mediator between the reader and language (Barthes, 1977: 143). Language thus appears for Friedrich as the ultimate expression of consciousness from which words (here, the words in the poem) are the means to express it.

The study of poetry is therefore valuable for the social scientist because it allows him/her to access this consciousness of the people, and consequently the culture that shapes such consciousness. If poetry is understood as a cultural artefact that comprises both what is said and what is not said (and which, in turn, are part of language since language is a product of a consciousness that is shaped at the same time by a culture), then the value of studying poetry for the social scientist must rest on its capacity of representing the access to the culture that shapes such a consciousness. The poem, like other literary texts, can be seen then as the result of different forces struggling between them; forces that are, to sum up, both external and internal, just as Pierre Bordieau also argued in "The Field of Cultural Production or the Economic World Reversed" (1983) when talking about what elements create the cultural product (Bourdieau, 1983 [1993]: 30).

\section{The Poems}

The poems selected in this article express that worldview that Friedrich refers to. They recognize and claim the existence of a Spanish heritage. Additionally, I have selected a fourth poem (Claro Mayo Recto's A los héroes del 96) that expresses the rejection of Spain as colonizer. The reason why I have selected that poem is to show how the Spanish-Philippine poetry at the turn of the nineteenth century was not reduced, politically speaking, to blame the United States and to praise Spain, but to blame any sort of oppressive power while a nationalism based on the presence of Spain was claimed.

The poems are structured as follows: Lines in italics correspond to the original in Spanish. Lines in quotation marks are a translation using a word-for-word approach. That means to say, they reproduce an exact word order, from Spanish to English. Next, lines with no italics and no quotation marks correspond to a translation using a sense-for-sense approach, which means, seeking a 
translation as faithful as possible in terms of sense/meaning/purpose from the original. As method of analysis, I will utilize close readings, focusing on symbolic details in order to develop an understanding of the texts' form and meanings. Ultimately, these close readings will show how the poems express a worldview of the Philippines not detached of (but influenced by) the Spanish country's heritage.

\section{RESULT AND DISCUSSION}

Claro Mayo Recto's A los héroes del 96 is a long poem that praises the people who led, in 1896, the revolution against the Spaniards, and from which the Philippines accomplished a theoretical independence from the metropolis before the definite end of the Spanish rule in 1898. The fragment here selected corresponds to the last verse of the poem, which is composed of ten stanzas. Recto's criticism towards the colonial rule of Spain does not exclude his acknowledgement of a Spanish heritage in the archipelago - he became the director of the Philippine Academy (the Philippine section of the Spanish Royal Academy of Language), and collaborated with the writing of the Philippine Constitution in 1936 (Veloso, 1960: 55):

\section{A los héroes del 96 (Claro M. Recto)}

¿Odio a todo extraño yugo, "Hatred to all strange yoke," Hatred to all foreign yoke,

conculcador de conciencias, "destroyer of consciences," trampler of consciences,

asesino de creencias, "killer of beliefs," assassin of beliefs, de libertades verdugo!

"of liberties executioner!"

executioner of liberty!

Corra el fecundante jugo

"Run the fecundous juice"

Let the fertile sap

de libertarias doctrinas;

"of libertarian doctrines;"

of libertarian doctrines flow

$y$ sobre las viejas ruinas

"and over the old ruins"

and on the old ruins

yérgase resplandeciente,

"stand up shining,"

resplendent stand,

libérrima e independiente

"entirely free and independent"

very free and independent

para siempre: ¡Filipinas!

"forever: Philippines!"

forever: the Philippines!

The stanza depicts Spain as conculcador de conciencias (trampler of consciences), asesino de creencias (assassin of beliefs) and de libertades verdugo (executioner of liberty). That is, as a hypocritical country that promotes the Catholic faith, but practices the destruction of other beliefs and individual freedoms. Such a portrait of Spain is connected with the need for a conscience of libertarian ideology, which Recto considers urgent in order to save the Philippines. Spain is therefore depicted as a country that has fallen behind other nations. Against those viejas ruinas (old ruins) that Spain represents, the Philippines' independence means strength and integrity. Recto is aware that the Spanish presence in the archipelago is the remains of something old, something from the past, something that needs to be 
gotten over. However, he also assumes the Philippine cultural identity as part of Hispanism, and therefore it is Spain as colonizer that has to be destroyed, yet not Hispanism. That is why he calls in the poem to stand up on the old ruins to build something new.

Recto was very critical with the American policy in the archipelago as well. His article "Monroísmo asiático" (1921) against the Monroe Doctrine is probably his most popular text (Farolán, 2002). He died in 1960 in Rome while travelling to Spain. His poem Las dalagas filipinas (1911) is a composition that praises both the beauty of the Philippine woman and the Philippine landscape. This connection between the woman and the Philippine landscape (dalaga means "woman" in Tagalog, and it is a word of the Spanish language ["dalaga," in Diccionario de la lengua Española of Real academia española de la lengua]) is a constant means in the Spanish-Philippine poetry. Here I have selected two stanzas of the poem.

\section{Las dalagas filipinas \\ (Claro M. Recto, 1911)}

\section{Todo un conjunto armónico y grato que} [envidiara

"All a harmonic and nice whole that would be envy"

An harmonic and nice whole that is the envy

\section{la ardiente castellana y la impasible} ["miss,"

"the ardent Castilian woman, and the insensitive 'miss,",

of the ardent Castilian woman and the insensitive miss,

la princesa que el cielo de Rusia cobijara

"the princess that the sky of Russia would shelter"

the princess that the sky of Russia would shelter y la dama que siente la fiebre de París.

"and the lady who feels the fever of Paris"

and the lady who feels the frenzy of Paris.

Quien dice que no es bella la mujer [filipina,

"Whoever says it is not beautiful the Philippine woman,"

Whoever says that the Philippine woman is not beautiful,

que visite estas tierras de Burgos y Rizal, "he/she must visit these lands of Burgos and Rizal,"

he should visit these lands of Burgos and Rizal,

y verá que es más mística, más dulce y [más divina,

"and he/she will see it is more mystical, sweeter and more divine,"

and he will see that is more mystical, sweeter and more divine,

la hija de los rajahs, la niña tropical. "the daughter of the rajahs, the tropical girl."

than the daughter of rajahs, the tropical girl.

In these stanzas, the poetic voice contrasts the Philippine woman with four types of women: the hieratic English, the aristocratic Russian (the poem is dated in 1911, so Recto is meaning the Czarist Russia), the frivolous lady living the Parisian Belle époque, and the ardent Castilian woman. "Ardent Castilian" must not be understood in a sexualized way. Instead, the poetic voice refers to the prototypical Castilian femininity that depicts woman as a strong, very brave person due to the hardness of the Castilian plateau and as opposed to the sensualized Andalusian woman. By the confrontation of these four types of 
women, the poetic voice characterizes four countries, from which Spain represents the strength, thus making the Philippines being envied. When, in the subsequent stanza, it is said: Quien dice que no es bella la mujer filipina, que visite estas tierras de Burgos y Rizal, Recto considers the Philippines a country where Spain has a presence.

While Rizal is the Philippines' national hero, Burgos is the center of the former Crown of Castile, geographically located in the Castilian plateau. The poetic voice thus associates Spain with Castile, ignoring the rest of the regions of the country. This can be interpreted in different ways. For example, it can be seen with the purpose of associating Spain with a glorious past where the Crown of Castile was the center of the Empire and, in a more hypothetical approach, it can be seen as a reproduction of what, during the first half of twentieth century, was developed in Spain as well: the search of hispanidad (Spanishness) in the Castilian heritage, which could help bring together the Spanish citizenship in a highly convulsed period of time. A third possibility might be that the Spanish spoken in the Philippines, unlike the Spanish-American variations, always had as a reference the Spanish spoken in the center-North of the Iberian Peninsula, and thus the Castilian culture.

If Recto's approach to the Spanish heritage of the Philippines can be seen as limited or biased because of this correlation between Castile and Spain, Fernando María Guerreros (1873-1929) is one of the most sincere and clearest supporters in claiming a Philippine identity rooted in Hispanism. A Hispania is a poem written in 1913 where he openly expresses, by means of the literary figure of Don Quixote, this Hispanism, and his rejection of the Americans:

\section{A Hispania \\ (Fernando María Guerreros, 1913)}

¡Oh, noble Hispania! Este día

"Oh, noble Hispania! This day"

O, Noble Spain! Today

es para ti mi canción, "is for you my song," this song is for thee.

canción que viene de lejos "a song that comes from far away"

A song that comes from afar

como eco de tu antiguo amor, "as echo of your ancient love," like an old love

temblorosa, palpitante "trembling, palpitating," trembling, palpitating

y olorosa a tradición

"and fragrant of tradition" fragrant with tradition

para abrir sus alas cándidas "to open their candid wings" opening its candid wings

bajo el oro de aquel sol "under gold of that sun" under the goldness of that sun of yours

que nos metiste en el alma

"that you put in us in the soul" which we've received into our souls

con el fuego de tu voz

"with the fire of your voice" with the fire of thy voice

y a cuya lumbre, montando, "and to whose fire, riding," in whose brightness ride

clavileños de ilusión, "clavileños of illusion" 
the stallions of hope.

mi raza adoró la gloria

"my race adored the glory

My race adored the glory

del bello idioma español, "of the beautiful Spanish language," of the beauty of the Spanish tongue

que parlan aún los Quijotes "that still speak the Quixotes" that is spoken by the Quixotes

de esta malaya región, "from this Malay region" from this Malay región,

donde quieren nuevos Sanchos, "where want new Sanchos" where new Sanchos would like

que parlemos en sajón.

"that we speak in Saxon."

that we instead spoke in Saxon tongue.

The mention of Don Quixote and Sancho is what interests me here. The poetic voice associates the Philippine people with Don Quixote, and the Americans with Sancho, thus establishing the well-known connection of the former with the notion of idealism and nobility, and the latter as the voice of realismi.e., the companion who constantly reminds the existence of a depressive reality (Flores, 1970: 178-179; Juliá, 1993: 275-276, Vadillo, 2013: 117-118). In Miguel de Cervantes' El ingenioso hidalgo Don Quijote de la Mancha (1605-15), Sancho is the voice of reason; the man who sees reality just as it is and who tries to prevent his master from pursuing his noble (but anachronistic) ideals of honesty because those ideas do not have place in the world they live. This parallelism is what Guerreros establishes. In Don Quijote, Sancho acts many times as the negative voice of the story because he is constantly questioning the purity of Don Quixote. $\mathrm{He}$ is also portrayed as an ignorant person, despite the fact that he repeatedly gives signs of being more lucid than his master is. Guerreros seems to argue that the American attitude of educating the Philippines (these embodied with the characteristics of Don Quixote, and never ready to surrender their idealistic nature sustained in the noble ideals that the Spanish language represents) is ignorant and very negative.

There is another reference in the poem (clavileños de ilusión) to Don Quijote. Clavileño is the name of a wood horse that Don Quixote and Sancho ride to travel through the universe in an episode (Vol. 2, Chapter 41). It is a fake trip; just the product of a joke by a group of people whom they know. When the poetic voice uses the name of this horse, it is not only refers to one of the most famous episodes of Cervantes' novel, but also idealizes the episode itself and its naïve, pure meaning. Just as Clavileño represents the purity of an illusion, the Philippines appear to be embodied with purity and illusion because they were educated in such values by means of the (trembling, palpitating and beautiful) Spanish language.

The last poem selected is Jesús Balmori's Blasón, which, like Guerreros', adheres to a romantic vision of Spain in order to extol a Hispanic Philippine identity:

\section{Blasón \\ (Jesús Balmori)}

Soy un bardo indo-hispano. En mi pecho cristiano

"An Indo-Spanish bard I am. In my breast,"

I am an Indo-Hispanic bard. In my Cristian chest,

mi corazón es vaso donde mezclada está 
"my Christian heart is a glass in which is mixed"

my heart is a glass where is mixed

la sangre de Legazpi, el Capitán hispano, "the blood of Legaspi, the Spanish captain,"

the blood of Legaspi, the Hispanic captain,

con la sangre tagala de la hija del Rajá. "with the Tagalog blood of the daughter of the Rajah."

with the Tagalog blood of the daughter of the Rajah.

Con el talón hundido en olas y en espumas,

"With heel submerged in waves and foam,"

With the heel submerged in waves and foams,

esperé sobre el mar el galeón español,

"I waited on the sea for the Spanish galleon,"

I waited on the sea the Spanish galleon,

y España, al encontrarme, besó las áureas plumas

"and Spain, upon finding me, kissed the white plumes"

and Spain, when she found me, kissed the golden plumes

que en mi frente temblaban como rayos de sol.

"that on my brow were trembling like the rays of sun"

that on my brow trembled as rays of sun.

Era hermosa, era buena, era plena de amores;

"Beautiful was she, kind, full of love;" She was beautiful, she was good, she was full of love;

Puse a sus pies mis lanzas, mis espigas, mis flores:
"At her feet I placed my lances, my spikes, my flowers,"

I put my lances at her feet, my spikes, my flowers:

Le di mi corazón salvaje y oriental;

"My savage and Oriental heart I gave to her;"

I gave to her my savage and oriental heart;

$y$ desde entonces va en mi pecho desnudo

"And since then she is on my naked breast"

and since then she goes in my naked chest

sirviéndome de férreo y de glorioso escudo

"serving me as iron and glorious shield" serving me as iron and glorious shield

con su idioma divino y su sangre inmortal.

"with her divine language and immortal blood."

with her divine language and her immortal blood.

Blasón is the only poem here selected that more evidently establishes a dichotomy between a civilized Spain and a savage Philippine. This is appreciated, for instance, in the third stanza, which considers Spain as beautiful (hermosa), good (buena) and full of love (llena de amores), and the only thing the Philippines can do is to put both material (lanzas-lances) and natural resources (espigas-spikes, and flores-flowers) at her feet. On the contrary, the poem sees the Philippine before the arrival of the Spaniards as savage and oriental; a place that was lucky to meet the Spaniards because, since then, they [the Philippines] have been protected by the Spanish language and the Spanish blood. The use of divino (divine) for characterizing Spanish, and inmortal 
(immortal) for characterizing the blood of Spaniards, denotes the religious connotations of the poem. These two elements (language and religion) are constant means in Spanish-Philippine poetry (Ortuño Casanova, 2014: 159). The attempt of moral restitution between Spain and the Philippines after the end of the colonial days happens for those writers who wrote in Spanish that the Spanish heritage in the Philippines mostly rests on language and religion (Ortuño Casanova, 2014: 166). Other poems that explore this connection between language and religion are Fernando Maria Guerreros' La fuerte caución or Manuel Bernabe's Filipinas a España, They reflect the idea that the Catholic religion is inherently attached to the Spanish language and, by extension, to the Philippine identity. Hence, language, religion and Spain's history appear intertwined and as makers of the Philippine cultural identity in these poems of turn-of-the-century Philippines.

\section{CONCLUSION}

Although the number of poems here selected is limited, that does not mean there were no other writers who wrote in Spanish. Isidro Marfori (1890-1949), Lorenzo Pérez Tuells (1898-1956), Cecilio Apóstol (1877-1938), and Enrique Fernández Lumba (1899-1990) are also writers worthy of attention. There were women writers as well: Evangelina E. Guerrero-Zacarías (190449), Adelina Gurrea y Monasterio (18961971) and Nilda Guerrero Barranco. In general, all of them moved around identical ideas: the similarities between the woman and the Philippine landscape; the sadness because of the progressive loss of Spanish; a purposeful use of sensorial iconography (intense colours, smells, exoticism...); or an idealization of Spain that can be understood as way of making the mother country exotic
(Ortuño Casanova, 2014: 167). Moreover, it is important not to forget that these writers were related, to some extent, to Spain. They knew the country due to their high social status, and most of them had the chance to travel to Europe.

The questions that derive from this point are very clear then: is it possible, today, to state that the Philippine cultural identity cannot be understood without the presence of a Hispanic element? In addition, is it possible to talk about Spanish-Philippine poetry just as it is talked about Spanish Peninsular poetry or a Spanish-American poetry/poetry, and which would help depict Philippine culture? In which way both these Philippine Modernist writers of the first half of the twentieth century and their poems can be considered reliable sources for the study of the Philippine culture today? And considering the current situation of Spanish in the archipelago (almost extinguished, but still remaining as a symbol of prestige and high social status), how representative of the Philippine cultural identity is the worldview that this sort of poetry offers?

It would be inaccurate and unfair, to conclude, to ignore that nowadays there are initiatives and projects which continue exploring this claim of a Spanish-Philippine cultural identity. In addition to the growth of the teaching of Spanish in schools and the efforts of Gloria Macapagal-Arroyo to reintroduce the knowledge of the Spanish heritage in the archipelago, initiatives as Revista Filipina, an online magazine exclusively dedicated to Philippine writers and intellectuals who write in Spanish, are praiseworthy. In addition to this, scholars such as Isaac Donoso have done extensive research regarding the presence of Arabs in the archipelago before the arrival of Spaniards in 1541 (2011, 2013, 2015), and the Academia Filipina de la Lengua often offers several seminars and 
lectures. The Philippines is also a member of Real Academia Española de la lengua, and it collaborates with the rest of Spanish-speaking countries in the updating of changes of Spanish around the world. However, many of the efforts to promote Spanish between Philippine people are still heavily funded by (and therefore depending on) Spain's government. Between the younger generations, Spanish is perceived as something very far away. They know of its existence in the history of the archipelago, but they do not speak it, using English or Tagalog instead. As stated before, Rodrigo Duterte's govern has supposed a setback of the work undertook by Macapagal's govern.

There is, in conclusion, much work to do, and the study of SpanishPhilippine literature (whether novel, or poetry or any other form) inside the field of Hispanism is a good way to help promote this part of the Spanish-speaking world. Spanish-Philippine poetry does offer motifs to consider the Philippines as part of the world of Hispanism, not as something exotic or part of an isolated episode of colonization, but on the same level as both Spanish Peninsular and Spanish-American literature. As asserted by Lifshey (2011), in a globalized world as we live in, the study of a literature of an Asian country written in a European language because of the presence of an American country detents a lot of sense.

\section{REFERENCES}

Alvar, Manuel (1996). Manual de dialectología hispánica: El español de América. Barcelona: Ariel.

Barthes, Barthes (1977). The Death of the Author. Image, Music, Text. Trans. Stephen Heath. New York: Hill. Wang: 142-148.
Bordieu, Pierre (1993). The Field of Cultural Production or the Economic World Reversed. The Field of Cultural Production: Essays on Art and Literature. Ed. Randall Johnson. Columbia University Press: 29-73.

Cervantes, Miguel de (1978). El ingenioso hidalgo Don Quijote de la Mancha. 2 vol. Madrid, Castalia.

"dalaga" (undated). Real Academia Española de la lengua. Retrieved from https://dle.rae.es/dalaga

Donoso, Isaac (2015). Ennoblece. Historia de las instituciones de la comunidad española en Filipinas. Manila, S.E.B.

Donoso, Isaac (2013). Islamic Far East: Ethnogenesis of Philippine Islam. Quezon, Universidad de Filipinas.

Donoso, Isaac and Andrea Gallo (2011). Literatura hispanofilipina actual. Madrid, Verbum.

Farolán, Edmundo (2002). Una perspectiva histórica de la poesía hispanofilipina, El tintero de tonos. Retrieved from https://www.um.es/tonosdigital/znu m7/tintero/hispanofilip.htm

Flores, R. M. (1970). Sancho's Fabrications: A Mirror of the Development of His Imagination. Hispanic Review 38.2: 174-182.

Friedrich, Paul (1996). The Culture in Poetry and the Poetry in Culture. Culture/Contexture. Explorations in Anthropology and Literary Studies. Eds. E.V. Daniel and Jeffrey Peck, Berkeley: University of California Press: 37-57. 
Gómez Rivera, Guillermo. En defensa del español en Filipinas. Viajar en Filipinas, (original letter dated on 2009 and republished in 22 June, 2012). Retrieved from https://viajarfilipinas.wordpress.co m/2012/06/22/en-defensa-delespanol-en-filipinas/

González Pola, Manuel (1992). Evangelización de los Dominicos en Filipinas en los siglos XVI y XVII. Cuadernos de misionología 6: $1-50$.

Juliá, Mercedes (1993). Ficción y realidad en Don Quijote (Los episodios de la cueva de Montesinos y el caballo Clavileño). Actas del Tercer Coloquio Internacional de la Asociación de Cervantistas. Alcalá de Henares: 275-279.

Lifshey, Adam (2011). Allegory and Archipelago: Jesus Balmori's Los pájaros de fuego and the Global Vantages of Filipino Literature in Spanish. Kritika Kultura 17: 5-22. Retrieved from https://journals.ateneo.edu/ojs/inde x.php/kk/article/view/KK2011.017 $\underline{01 / 1443}$

Lipski, John (1986-87). Contemporary Philippine Spanish: Comments on Vestigial Usage. Philippine Journal of Linguistics 17.2-18.1: 37-48.

Ortuño Casanova, Rocío (2014). La representación de España en la poesía filipina en castellano de la época de ocupación americana: idealización, exotización y diferenciación. Transmodernity: Journal of Peripheral Cultural Production of the Luso-Hispanic World 4.1: 154-167. Retrieved from http://www.cervantesvirtual.com/o bra/la-representacion-de-espana-enla-poesia-filipina-en-castellano-dela-epoca-de-ocupacion--americanaidealizacion-exotizacion-ydiferenciacion/

Pharies, David A. (2008). Breve historia de la lengua española. Chicago and London: The University of Chicago Press.

Quilis, Antonio (2003). Historia externa del español en Asia. Romanische Sprachgeschichte: ein internationals Handbuch zur Geschichte der romanischen Sprachen 1: 1060-1069.

Quilis, Antonio (1992). Los estudios sobre la lengua española en Filipinas. Scripta philologica: in honorem Juan M. Lope Blanch, a los cuarenta años de docencia en la UNAM y a los 65 años de su vida: 661-672.

Rafael, Vicente J. (1999). Translation and Revenge: Castilian and the Origins of Nationalism in the Philippines. The Places of History: Regionalism Revisited in Latin America. D. Sommer (Ed.): 214235.

Revista filipina. Retrieved from https://revista.carayanpress.com/

Richmond Ellis, Robert (2012). They Need Nothing: Hispanic-Asian Encounters of the Colonial Period. Toronto, Buffalo, London: University of Toronto Press.

Rodao, Florentino (1997). Spanish Language in the Philippines: 19001940. Philippine Studies 45.1: 94107. 
Salvetti, Francisco (2019). Literary Modernism in Latin America. 23 Nov. 2019. Retrieved from https://franciscosalvetti.com/literar y-modernism-latin-america

Shank, Burguess (1903). Education in the Philippines: A Reply. Gunton's Magazine (1898-1904): 406.

Vadillo, Juan (2013). El delirio frente a la razón en el Quijote. Acta Poética 34.2: 103-126. Retrieved from https://www.sciencedirect.com/scie nce/article/pii/S0185308213724052

Veloso, Alfredo (1960). Anguish, Fulness, Nirvana: A Collection of Famous Poems in Spanish Written by Filipino Writers, and Corresponding Translations into English. Trans. and Ed. Alfredo Veloso. Quezon City: Asvel Publishing Co.

Wilson, Woodrow (1908). Constitutional Government in the United States. New Jersey: Columbia University Press.

Zamora Vicente, Alonso (1967). Dialectología hispánica. Madrid: Gredos. 